\title{
PREPARING TEACHERS TECHNICAL EDUCATION AND INFORMATION ON THE FACULTY OF EDUCATION IN OLOMOUC
}

Čestmír SERAFÍN*, Univerzita Palackého v Olomouci, Česká republika

Přijato: 4. 1. 2017 / Akceptováno: 22. 2. 2017

Typ článku: Teoretická studie

DOI: $10.5507 /$ jtie.2017.005

Abstract: The paper deals with the changes in teacher training in technical disciplines involved and implementing the teaching at primary or secondary schools. Study upper secondary school teacher training in technical and information education in full-time or combined full-time and distance learning aims to allow both to satisfy nationwide demand for the study of technically and technologically-oriented disciplines and at the same time indirectly to bring the "spirit" of technology into the school educational programmes thanks to the approbation of the graduates - teachers. Presented the paper with regard to the above deals with, firstly identifying the appropriate educational tools an innovative approach to teacher training in the given field of study, firstly, identifies the educational concept of developing these tools in the field.

Key words: Technical Education; field of study; pedagogy; technique; informatics; teaching; innovation.

\section{PŘÍPRAVA UČITELŮ TECHNICKÉ A INFORMAČNÍ VÝCHOVY NA PEDAGOGICKÉ FAKULTĚ V OLOMOUCI}

Abstrakt: Přispěvek se zabývá změnami v připravě učitelů technicky orientovaných disciplín působicích a realizujicich výuku na základnich, případně středních školách. Studium učitelství technické a informační výchovy v prezenční $i$ v kombinaci prezenční a distanční formy má za cíl umožnit jednak uspokojit celospolečenskou poptávku po studiu technicky a technologicky orientovaných oborü a zároveň neprímo vnést „duch“ techniky do školnich vzdělávacích programi̊ diky aprobaci absolventů - učitelü. Předkládaná stat'se s ohledem na výše uvedené zabývá jednak identifikováním vhodných vzdělávacích nástrojů inovativního pojetí prípravy učitelů daného oboru, jednak identifikuje vzdělávaci koncept rozvijejíci tyto nástroje v dané oblasti.

Klíčová slova: Technická výchova; studijní obor; pedagogika; technika; informatika; učitelství; inovace.

*Autor pro korespondenci: cestmir.serafin@upol.cz 


\section{1 Úvod}

Současný školský systém v České republice rozlišuje všeobecné základní technické vzdělávání a vzdělávání profesní. V tomto pojetí pedagogická praxe hledá optimální podobu technicky a informačně komunikačně technologicky zaměřených předmětů jako součásti struktury školského a společenského systému přinášejícího nejen technické vědomosti, dovednosti a uživatelskou prosperitu, ale také pochopení důsledků technického rozvoje a podílu zodpovědnosti jedince za budoucnost.

Současné společenské myšlení považuje techniku za jeden z určujících faktorů lidské existence, ovlivňující životní styl člověka i jeho perspektivní civilizační vývoj. Pod úhlem tohoto poznání dostává oblast techniky svoje nutné a objektivní místo $\mathrm{v}$ přípravě člověka na život. Je-li tato skutečnost samozřejmostí z hlediska profesního, není dosud vždy jednoznačně respektována v systému všeobecného základního vzdělávání. I volba technických profesí žáky je tímto rozporem zatížena a projevuje se v profesní orientaci žáků v dalších letech.

Jednou z podmínek úspěchu je nejen aktualizace obsahu technicky zaměřených předmětů v závislosti na měnící se společenské potřebě (viz školská reforma a vývojové trendy ve školství, společenský informační boom), ale také objasňování širších souvislostí techniky $\mathrm{v}$ duchu současných reformních vzdělávacích snah jako součást př́ipravy žáků pro úspěšný občanský život podmiňující celospolečenské klima.

Dnešní postindustriální nebo spíše informační společnost je charakterizována podstatným využíváním digitálního zpracování v uchování a přenosu informací. Ze zpracování informací se tak stává významná ekonomická komodita, která prostupuje tradičními ekonomickými či společenskými aktivitami a vytváří zcela nové prŕležitosti a činnosti, které podstatně ovlivňují charakter společnosti. Informační a komunikační technologie (ICT) prezentují specifickou oblast techniky zahrnující soudobé digitální technologie zpracování, uchování a přenosu informací a komunikace založené na počítačích, multimediálních systémech, mobilních komunikačních prostředcích a zvláště pak na Internetu. Rozvoj ICT vede k přenosu akcentu ekonomických aktivit společnosti z průmyslové výroby do oblasti zpracování informací a symbolických manipulací.

Vzdělávání učitelů technických předmětů tak zákonitě reflektuje výše uvedené oblasti a to zejména $\mathrm{v}$ kontextu požadavků odborné praxe. V roce 2015 proběhlo např́iklad diskusní fórum „Kvalita vzdělávání: Kde jsme a kam směrujeme?“, které bylo organizováno Svazem průmyslu a dopravy České republiky. Podle šetření ${ }^{1}$, které tento svaz organizoval, téměř 30 procent zástupců firem poukazuje na problém kvality učitelů, a to i ve spojitosti $\mathrm{s}$ jejich nízkým finančním ohodnocením. Průzkum rovněž potvrdil skutečnost, že zaměstnavatelé nemají dostatek absolventů technických oborů. Chybí absolventi všech stupňů škol. Nejvíc není uspokojena jejich poptávka po vysokoškolácích (58\%), následují středoškoláci s maturitou (44 \%) a poté stř̌edoškoláci s výučním listem $(36 \%)$.

Návrhy Svazu průmyslu a dopravy České republiky na zvýšení kvality vzdělávání, se zaměřují na:

a) kvalitu žáků a studentů

podpora technické výchovy, polytechnických předmětů a materiálního vybavení;

${ }^{1}$ Další informace lze najít na www.spcr.cz. 
- podpora zájmového technického vzdělávání, podpora nových soutěží technického zájmového vzdělávání, podpora školních kroužků;

b) kvalitu pedagogů

- návrh systému metodické pomoci pedagogům a sdílení dobré praxe výuky (metodici, předmětová sdružení učitelů, mentoring);

- návrh kariérního systému vč. jeho financování (jednou z kvalifikačních cest učitele musí být též odborná profilace, vázaná mj. na stáže učitelů v podnicích);

- $\quad$ změny $\mathrm{v}$ pregraduální př́ípravě (pedagogické VŠ) - úpravy vzdělávacích programů tak, aby byla navýšena praktická část přípravy studentů v reálném školním prostředí a větší relevance výuky vzhledem ke změnám forem výuky a využití ICT ve výuce;

- propagace inovativních metod výuky př́rodovědných a technických předmětů na ZŠ a SŠ;

- $\quad$ stáže učitelů odborného vzdělávání v podnicích;

c) kvalitu a obsah vzdělávacích programů

revize Rámcových vzdělávacích programů, provázání se standardy Národní soustavy kvalifikací, zveřejnění harmonogramu revizí celé soustavy RVP vč. její redukce.

Je potřeba v této souvislosti také uvést, že dle výzkumu Centra pro výzkum veřejného mínění Sociologického ústavu AV ČR s názvem „Naše společnost 2013“2 bylo respondenty uvedeno, že mezi pět prestižních povolání vnímané českou veřejností patří povolání učitel (z 26 profesí). Z tabulky č. 1 je patrné, že povolání lékaře se dlouhodobě udržuje $\mathrm{v}$ žebříčku prestiže vybraných profesí na první pozici převážně s více než desetibodovým odstupem před ostatními profesemi, ale zároveň povolání učitel základní školy dosahuje standardně přes $70 \%$. V tomto výzkumu je také uvedeno, že maximum 99 bodů bylo uděleno každé profesi alespoň jednou (tj. i těm profesím, které zaujímají poslední místa $\mathrm{v}$ žebrríčku), avšak více než tři procenta dotázaných (více než 30 respondentů) udělilo maximum bodů právě profesi učitel na základní škole $(4,8 \%)$ a vysokoškolskému učiteli (5,9\%).

\begin{tabular}{|l|c|c|c|c|c|c|c|c|}
\hline \multicolumn{1}{|c|}{ Profese } & \multicolumn{2}{c|}{2004} & \multicolumn{2}{c|}{2007} & \multicolumn{2}{c|}{2011} & \multicolumn{2}{c|}{2013} \\
\hline & průměr & pořadí & průměr & pořadí & průměr & pořadí & průměr & pořadí \\
\hline Lékař & 89,5 & 1. & 89,8 & 1. & 89,1 & 1. & 91,5 & 1. \\
\hline Vědec & 80,7 & 2. & 81,8 & 2. & 75,4 & 2. & 76,3 & 2. \\
\hline $\begin{array}{l}\text { Zdravotní } \\
\text { sestra }\end{array}$ & & & & & 73,9 & 3. & 74,8 & 3. \\
\hline $\begin{array}{l}\text { Učitel na } \\
\text { yysoké škole }\end{array}$ & 78,5 & 3. & 78,2 & 3. & 72,4 & 4. & 74,6 & 4. \\
\hline $\begin{array}{l}\text { Učitel na } \\
\text { základní škole }\end{array}$ & 74,3 & 4. & 70,7 & 4. & 70,3 & 5. & 71,1 & 5. \\
\hline
\end{tabular}

Tabulka č. 1 Prestiž povolání (průměrné bodové hodnocení) v letech 2004-2013

\footnotetext{
${ }^{2}$ http://cvvm.soc.cas.cz/media/com_form2content/documents/c1/a7054/f3/eu130903.pdf
} 


\section{Použité metody}

Při zpracování byly užity především informační prameny, nesoucí charakter teoretických metod pedagogického výzkumu. Prováděna byla klasifikační a vztahová analýza zejména vzdělávací dokumentace a ve studiu publikovaných vědeckých statí, i kurikulárních dokumentů. Excerpované poznatky byly podrobeny komparativní analýze a kritickému hodnocení $\mathrm{s}$ cílem usporádat je do souvislostí rámce $\mathrm{v}$ kontextu prípravy budoucích učitelů. Ve vybraných částech byla uplatněna snaha popisovat problémy spojené s fenomény, které se vyskytují ve společnosti, resp. mající vliv na vzdělávací teorii a následnou praxi s akcentem na oborovou didaktiku.

Užity byly rovněž analyticko-syntetické prístupy a to zejména $\mathrm{v}$ kontextu porozumění vztahům platným ve vzdělávacích systémech se zaměřením na všeobecně pojaté technické vzdělávání.

\section{Oborová didaktika jako předpoklad kvality učitele technické výchovy}

Oborové didaktiky jsou obecně považovány za vědní disciplíny orientující se na oborově specifickou oblast učení ve škole ale i mimo ni. Jejich dosah v oblasti teorie, praxe a výzkumu sahá od vymezování cílů oborové výuky přes výběr, didaktickou transformaci obsahů až $\mathrm{k}$ metodice učících procesů, přičemž jsou vždy zohledňovány psychické, sociální a dalších předpoklady jak na straně žáka i učitele 3 .

Součástí pedagogiky řešící oborově didaktické problémy je mj. také technická výchova. Tato však je na rozdíl napríklad od matematiky, fyziky či hudební výchovy v mnohém specifická - kromě metod či cílů, je tím specifičnem především obsah.

Cílem technické výchovy je především vytváření vědomostí o technice (její výrobě, užití, likvidaci, materiálech, technologiích apod.) ve všeobecné rovině, tj. základních uživatelských dovedností při činnosti s technikou, správných postojů $\mathrm{k}$ ní, ale podílí se i na profesní orientaci žáků. Svým zaměřením technická výchova umožňuje žákům získat nezbytný soubor vědomostí, pracovních dovedností a návyků potřebných $\mathrm{v}$ dalším vzdělávání, pracovním i běžném životě a formuje osobnost žáka rozvíjením kladných vlastností, motorických i tvořivých schopností a dovedností. Touto problematikou se dlouhodobě zabývá ve svých pracích mnoho význačných odborníků např́ílad M. Scigiel (1986), I. Turek (1990), J. Bajtoš a J. Pavelka (1999), J. Drahovzal, O. Kilián a R. Kohoutek (1997), Z. Friedmann (1993), J. Kropáč, Kubíček a V. Hajda (1996), F. Mošna (1992), J. Kropáč, Z. Kubíček, M. Chráska a M. Havelka (2004), J. Dostál (2011) a další.

J. Stoffa (1994) chápe technickou výchovu jako systematický a řízený proces záměrného formování osobnosti ve vztahu $\mathrm{k}$ technice tak, aby vychovávaný získal $\mathrm{v}$ procesu výchovy správné postoje $\mathrm{k}$ technice a $\mathrm{k}$ využívání techniky v životě. Dále požaduje, aby tyto cíle byly dosahovány na vědeckém základě, uvědoměle a při aktivitách majících vztah $\mathrm{k}$ technice, $\mathrm{s}$ níž se $\mathrm{v}$ životě setká každý jedinec a která může mít vliv na jeho život nebo na společenský život. Uvedené lze plně pokládat za výstižnou charakteristikou základního všeobecně pojatého technického vzdělávání.

Katedra technické a informační výchovy Pedagogické fakulty Univerzity Palackého v Olomouci garantuje studium zaměřující se na př́ípravu učitelů základních, př́padně středních škol ve všeobecně pojatém vzdělávacím obsahu technické výchovy, která je

${ }^{3}$ Gesellschaft für Fachdidaktik (http://fachdidaktik.org) a v kontextu vymezeném příspěvkem pak Deutsche Gesellschaft für Technische Bildung (http://www.dgtb.de) 
součástí vzdělávací oblasti Člověk a svět práce vymezeném v Rámcovém vzdělávacím programu pro základní vzdělávání. Př́́prava učitelů se zde zaměřuje na poskytování studentům učitelství integrované znalosti a dovednosti vycházející didaktiky technické výchovy, z pedagogických a psychologických disciplín s oporou o aktuální výzkumné poznatky, dovednosti reflexe procesu výuky na odpovídajících typech a stupních škol, dovednost sebereflexe v roli učitele a přijetí morálních závazků a etiky učitelství.

Pochopitelně významnou otázkou je, jaká kritéria při koncipování př́pravy budoucích učitelů technické výchovy zvolit. Pedagogická teorie přináší řadu kritérií a požadavků na ně. Pro technické předměty, vzhledem $\mathrm{k}$ jejich charakteru, lze za dobrý soubor kritérí vyplývat z konceptu tzv. „smysluplného učení, viz práce J. Mareše (2013). Toto učení zahrnuje sedm charakteristik směřujících na žáky, které by měly najít svůj odraz právě v prrípravě budoucích učitelů: aktivní (aktivnost učení), konstruující (konstruktivnost učení), kumulativní, autoregulované, zacílené, situované, a individuálně odlišné. Vysvětlení této problematiky, jak je provedl J. Mareš (2013), je zvláště dobře aplikovatelné na technické předměty.

Při koncipování obsahu studijního programu lze pak vycházet jak z podnětů odborné praxe a pak také pochopitelně ze základního rámce vymezeného Rámcovým vzdělávacím programem a kontextu oblasti nižšího sekundárního i vyššího sekundárního vzdělávání (ISCED 2, ISCED 3). Pojetí studijní dokumentace musí respektovat možnosti budoucího uplatnění absolventů studia ve školách (v souladu se zákonem č. 563/2004 O pedagogických pracovnících) v široké oblasti vzdělávání s bližším akcentem na soudobé trendy ve vzdělávání, odrážející vlivy uplatnění výsledků technických věd i informačních a komunikačních technologií ve společnosti. Zde lze vidět i potřebu více deklarovat oblast, pro kterou je nutné připravovat absolventy studijního oboru, tj. školská sféra a vzdělávání.

Boloňský proces znamenal vytvoření Evropského prostoru vysokoškolského vzdělávání zahájeného Boloňskou deklarací ${ }^{4}$ o zavedení srovnatelnějšího, slučitelnějšího a jednotnějšího systému evropského vysokoškolského vzdělávání. Jeho cílem bylo vytvořit systém vysokoškolských studií, které jsou snadno rozeznatelné a srovnatelné, podporovat mobilitu a zajistit vysokou kvalitu učení a výuky. V souladu s tímto procesem se př́prava učitelů děje v České republice (až na výjimky) dvoustupňově, tj. na bakalářském a navazujícím magisterském stupni.

V kontextu Boloňské deklarace $\mathrm{v}$ oblasti strukturovaného učitelského vzdělávání tak výše uvedené znamenalo možnost vstoupit do učitelského studia různými cestami, napřr. zvolit si bakalářský studijní program zaměřený na vzdělávání, kdy již od počátku studia student proniká do problémů výchovy a vzdělávání, nebo se rozhodnout pro učitelské studium až po absolvování odborného bakalářského studia a učitelství studovat v př́slušném navazujícím magisterském studiu. Cest je však pochopitelně více.

V podmínkách Pedagogické fakulty Univerzity Palackého v Olomouci absolvent bakalářského stupně (viz. přehled náplně studia v tabulce č. 2) získá všeobecný rozhled a ovládne základní dovednosti a postupy širokého spektra technologií. Je tak prripraven, metodami akcentující činnostní pojetí, uplatňovat vědecké a technické poznatky, kreativní dovednosti a podněcovat $\mathrm{k}$ vytváření žádoucích vazeb a postojů $\mathrm{k}$ technosfére, $\mathrm{k}$ technice a $\mathrm{k}$ užití techniky a informačních technologií zejména ve vzdělávací oblasti.

${ }^{4}$ http://www.ehea.info/ 
Přitom je nutné zvláště zdůraznit, že tento absolvent je připravován tak, aby mohl především úspěšně pokračovat ve studiu navazujícího magisterského oboru.

\begin{tabular}{|l|c|}
\hline Název předmětu & Ročník/semestr \\
\hline Materiály a technologie I. & $1 / \mathrm{Z}$ \\
\hline Technická grafika & $1 / \mathrm{Z}$ \\
\hline Informační technologie ve vzdělávání & $1 / \mathrm{Z}$ \\
\hline Hardwarová a softwarová konfigurace PC & $1 / \mathrm{Z}$ \\
\hline Teoretické základy technických předmětů & $1 / \mathrm{Z}$ \\
\hline Matematika & $1 / \mathrm{L}$ \\
\hline Materiály a technologie II. & $1 / \mathrm{L}$ \\
\hline Bezpečnost práce & $1 / \mathrm{L}$ \\
\hline Základy konstruování & $1 / \mathrm{L}$ \\
\hline Technologie počítačových sítí & $1 / \mathrm{L}$ \\
\hline \hline Elektrotechnika I. & $2 / \mathrm{Z}$ \\
\hline Technické praktikum I. (dřevo, papír, textil) & $2 / \mathrm{Z}$ \\
\hline Grafické programy - CAD 1 & $2 / \mathrm{Z}$ \\
\hline Tvorba webových stránek & $2 / \mathrm{Z}$ \\
\hline Elektrotechnologie & $2 / \mathrm{Z}$ \\
\hline Části strojů a zařízení & $2 / \mathrm{Z}$ \\
\hline Úvod do algoritmizace a programování & $2 / \mathrm{Z}$ \\
\hline Elektrotechnika II. & $2 / \mathrm{L}$ \\
\hline Technické praktikum II. (kov, plast) & $2 / \mathrm{L}$ \\
\hline Databázové systémy & $2 / \mathrm{L}$ \\
\hline Základy programování & $2 / \mathrm{L}$ \\
\hline Grafické programy a multimédia pro vzdělávání & $2 / \mathrm{L}$ \\
\hline Grafické programy - CAD 2 & $2 / \mathrm{L}$ \\
\hline \hline Elektronika & $3 / \mathrm{Z}$ \\
\hline Praktikum z elektrotechniky & $3 / \mathrm{Z}$ \\
\hline Multimediální a prezentační tvorba & $3 / \mathrm{Z}$ \\
\hline Statistické zpracování dat & $3 / \mathrm{Z}$ \\
\hline Semináŕ k závěrečné práci & $3 / \mathrm{Z}$ \\
\hline Technické praktikum III. (strojní zpracování dřeva) & $3 / \mathrm{Z}$ \\
\hline Praktikum z programování 1 & $3 / \mathrm{Z}$ \\
\hline Dějiny techniky & $3 / \mathrm{Z}$ \\
\hline Praktikum z elektroniky & $3 / \mathrm{L}$ \\
\hline Teorie systémů & $3 / \mathrm{L}$ \\
\hline Technické praktikum IV. (strojní zpracování kovů) & $3 / \mathrm{Z}$ \\
\hline Praktikum z programování 2 & $3 / \mathrm{L}$ \\
\hline Programování webových aplikací & $3 / \mathrm{Z}$ \\
\hline Exkurze & $3 / \mathrm{Z}$ \\
\hline & \\
\hline & \\
\hline
\end{tabular}

Tabulka č. 2 Studijní plán bakalářského stupně v př́ípravě učitelů technické výchovy 


\begin{tabular}{|l|c|}
\hline Název předmětu & Ročník/semestr \\
\hline Didaktika technické výchovy I. & $1 / \mathrm{Z}$ \\
\hline Využití infor. a komun. technologií ve vzdělávání & $1 / \mathrm{Z}$ \\
\hline Tvorba výukového softwaru & $1 / \mathrm{Z}$ \\
\hline Didaktika technické výchovy II. & $1 / \mathrm{L}$ \\
\hline Didaktika informačních technologií & $1 / \mathrm{L}$ \\
\hline Základy mechatroniky a automatizace & $1 / \mathrm{L}$ \\
\hline Humanizační aspekty techniky & $1 / \mathrm{Z}$ \\
\hline Počítačové modelování a simulace & $1 / \mathrm{L}$ \\
\hline Speciálně didaktické praktikum I. & $1 / \mathrm{Z}$ \\
\hline Speciálně didaktické praktikum II. & $1 / \mathrm{L}$ \\
\hline \hline Svět práce & $2 / \mathrm{Z}$ \\
\hline Didaktika technických předmětů & $2 / \mathrm{Z}$ \\
\hline Moderní technologie & $2 / \mathrm{Z}$ \\
\hline Školní informační a komunikační systémy & $2 / \mathrm{L}$ \\
\hline Multimédia ve výuce & $2 / \mathrm{L}$ \\
\hline Multimediální didaktické praktikum & $2 / \mathrm{L}$ \\
\hline Diplomová práce & $2 / \mathrm{Z}$ \\
\hline
\end{tabular}

Tabulka č. 3 Studijní plán navazujícího magisterského stupně v př́ípravě učitelů technické výchovy

Cílem vzdělávání v navazujícím magisterském stupni (viz. přehled náplně studia v tabulce č. 3) je poskytovat ucelené, profesně orientované magisterské vzdělání připravující absolventa pro výuku vyučovacích předmětů, tematických celků, kurzů či projektů z oblasti technické výchovy, informační výchovy i informačních technologií ve školských institucích. Absolventi tak získávají př́slušné znalosti a dovednosti v oblasti technické výchovy, informační výchovy (včetně informačních a komunikačních technologií), soudobých didaktických koncepcí a př́stupů $\mathrm{k}$ výuce technicky a informačně zaměřených vyučovacích předmětů.

\section{Závěr}

Pojem technická výchova v souvislosti s technickým vzděláváním lze považovat za univerzální, perspektivní, co nejvíce trvalý obsah výuky, aplikovatelný v širokém spektru činností s technikou. Jde o porozumění souvislostem mezi technikou, ekonomikou, společností a přírodou při vlastní aktivní, samostatné, tvořivé činnosti žáka, připravující jej na řešení očekávaných situací spojených s technikou ve všech základních oblastech života. Tyto cíle jsou reflexí požadavků společnosti na všeobecné vzdělávání z hlediska moderní společnosti.

Global Digital Citizen Foundation v př́spěvku Six Essential Modern Teacher Skills (and Why You Need Them) ${ }^{5}$ přinesla určité shrnutí pohledů na současného učitele -

${ }^{5}$ https://globaldigitalcitizen.org/six-essential-modern-teacher-skills-need 
učitele budoucích generací a jeho kompetence, který má odraz v př́ípravu studentů učitelství technické a informační výchovy v Olomouci:

1) Přizpůsobivost - věk, ve kterém se nacházíme je pojímán jako věk digitální, predstavující neustálou „Změnu“ a to jak v pojetí technologickém, tak společensko-ekonomickém i kulturním.

2) Zvídavost - je snaha poznávat a dozvědět se něco nového.

3) Sebedůvěra - jedná se o sebedůvěru vlastní, důvěru ve vlastní schopnosti a dovednosti, ale také o důvěru v ostatní, ve své žáky.

4) Spolupráce - je důležitou podmínkou a vlastně prímo podstatou profese učitele. Svým př́stupem učitel ovlivňuje jak klima ve třídě, tak ve škole.

5) Charisma - je vlastnost osobnosti, dar vytěžit to nejlepší empatií či schopností povzbudit druhé k pozitivnímu myšlení. Učitel inspiruje a motivuje.

6) Globální myšlení - dnešní technologie mění svět, mění tím i vzdělávání samotné. Učitele je v této oblasti stěžejní pro své žáky ukazující jim jak možnosti, tak i rizika a nebezpečí.

Př́íprava učitelů technické výchovy, technických předmětů (i informačně zaměřených) je esencí všeho, co zde bylo řečeno přinášející kvalitní oborový základ pro učitele a jejich působení v praxi. $V$ tomto pojetí je také nově koncipován studijní obor na Pedagogické fakultě Univerzity Palackého v Olomouci, který je akreditován od roku 2015.

\section{Literatura}

Scigiel, M. (1986) Didaktika technické výchovy. Brno: Univerzita J. E. Purkyně.

Turek, I. (1990) Didaktika technických predmetov. Bratislava: Slovenské pedagogické nakladat'elstvo.

Bajtoš, J., \& Pavelka, J. (1999). Základy didaktiky technickej výroby. Prešov: Prešovská univerzita

Drahovzal, J., Kilián, O., \& Kohoutek, R. (1997) Didaktika odborných předmètů. Brno: Paido.

Friedmann, Z. (1993). Didaktika technické výchovy. Brno: Masarykova univerzita. Friedmann, Z. \& Pecina, P. (2013). Didaktika odborných predmètů technického charakteru. Brno: PdF Masarykova univerzita.

Kropáč, J., Kubíček, Z., \& Hajda, V. (1996). Didaktika technických předmětů vybrané kapitoly. Olomouc: Univerzita Palackého.

Kropáč, J. (Eds.) (2004). Vybrané kapitoly z didaktiky technických předmětů. Olomouc: Univerzita Palackého.

Mošna, F. (1992). Didaktika technické výchovy. 1. vyd. Praha: Univerzita Karlova.

Dostál, J. (2011). Teoretické základy technických predmètů (přednášky). Olomouc: UP. Kropáč, J., Kubíček, Z., Chráska, M. \& Havelka, M. (2004) Didaktika technických predmětu: vybrané kapitoly. 1. vyd. Olomouc, Univerzita Palackého.

Stoffa, J. (1994) Terminológia v technickej výchove. Nitra: Vysoká škola pedagogická. Mareš, J. (2013) Pedagogická psychologie. 1. vyd. Praha: Portál. 